\title{
PENELITIAN
}

\section{PERBANDINGAN BEBERAPA RUMUS UNTUK MEMPREDIKSI BERAT BADAN LAHIR BERDASARKAN PENGUKURAN TINGGI FUNDUS UTERI}

\author{
Dewi Gayatri*, Yati Afiyanti**
}

\begin{abstract}
Abstrak
Tujuan penelitian ini membandingkan rumus Niswander, Johnson, SML, SFH, dan modifikasi Niswander untuk mengestimasi berat badan janin yang akan lahir pada populasi Jakarta.Desain yang digunakan dalam penelitian ini adalah potong lintang, dimana pengambilan data dilakukan dengan menggunakan catatan rekam medik. Penelitian ini melibatkan 223 responden di Puskesmas Pembina Tebet, Jakarta. Hasil temuan penelitian ini adalah diketahui bahwa rumus Niswander, Johnson, SML, dan SFH tidak cukup valid untuk estimasi berat badan lahir janin untuk populasi ibu hamil di Indonesia $(\mathrm{p}=0,000)$. Hanya rumus modifikasi Niswander (dari Farid dan Sukarya) yang cukup valid untuk melakukan estimasi berat badan lahir janin untuk populasi tersebut $(\mathrm{p}=0,205)$. Kesimpulan dari studi ini adalah rumus-rumus untuk memperkirakan berat-badan lahir janin yang berasal dari penelitipeneliti Barat tidak sesuai digunakan untuk populasi ibu hamil di Indonesia.
\end{abstract}

Kata kunci: taksiran berat badan lahir janin; pengukuran tinggi fundus uterus; rumus.

\begin{abstract}
The purposes of the research were to compare Niswander, Johnson, SML, SFH, and Niswander's modified rules in estimating fetal birth weight on the Population in Jakarta. The design of this study was a cross-sectional that using the medical record. 223 respondens were participated in the study at Puskesmas Pembina Tebet, Jakarta. The result of this study showed that the Niswander's rule, Johnson's rule, SML's rule, and SFH's rule are not valid to estimate the fetal birth weight for the Indonesian pregnant population ( $p=0.000$ ) and only the modified Niswander's rule that enough to be valid on this population $(p=0.205)$. The conclusion of this study showed that the rules from the westerns researchers for estimating the fetal birth weight is not appropriate to be used the Indonesian pregnant.
\end{abstract}

Key words: estimated fetal birth weigth, measurement height of the fundus, rules.

\section{LATAR BELAKANG}

Pertumbuhan berat janin selama dalam kandungan merupakan salah satu indikator yang menentukan kesejahteraan janin. Pemeriksaan kesejahteraan janin penting dilakukan selama masa kehamilan. Keteraturan pemeriksaan tersebut dapat memberikan jaminan kepada setiap wanita hamil, untuk mendapatkan bayi yang sehat tanpa mengalami komplikasi selama masa perinatal.

Pertumbuhan berat janin yang sesuai dengan usia kehamilan menandai kesejahteraan janin yang optimal. Berbagai cara dapat dilakukan untuk memantau kesejahteraan janin sebagai contoh pemakaian ultrasonografi (USG)(Pillitery, 1999). Penggunaan USG tersebut digunakan untuk memperkirakan berat janin telah umum dijumpai pada rumah sakit-rumah sakit yang sudah memiliki fasilitas dan sarana pelayanan kesehatan yang cukup modern terutama di kota-kota besar. Pemeriksaan ini dipandang sebagai metode pemeriksaan non invasif yang cukup aman dan praktis dengan hasil pemeriksaan yang cukup akurat.

Ketersediaan alat ini masih sangat terbatas hanya pada rumah-rumah sakit besar yang sudah memiliki sarana dan fasilitas alat-alat kesehatan yang modern. Di puskesmas-puskesmas atau pada praktek-praktek bidan, terutama pada puskesmas-puskesmas yang ada dikota kecil atau daerah pedesaan, alat USG umumnya tidak tersedia. Selain belum banyak tersedia, biaya pemakaian dan perawatan alat ini juga relatif mahal. Hal ini sangat terasa memberatkan perekonomian klien terutama pasca krisis moneter dimana alat-alat kedokteran masih harus diimport dan dibayar dengan dollar. 
Pemeriksaan tinggi fundus uteri merupakan salah satu cara alternatif dalam mengkaji kesejahteraan janin, khususnya untuk memperkirakan taksiran berat janin (Pillitery, 1999). Alibasjah dan Hakimi, 1995 dalam penelitiannya menemukan bahwa adanya korelasi yang tinggi antara pengukuran TFU dengan pengukuran USG dalam memperkirakan taksiran berat janin (koefisien korelasi intrakelas $=0,8655$ ). Bothner, dkk (2000) menyatakan hal yang sama bahwa terdapat korelasi yang cukup baik antara pengukuran TFU dengan berat badan lahir $(\mathrm{r}=0,56)$.

Pemeriksaan tinggi fundus uteri dapat dilakukan untuk memprediksi berat janin dimana fasilitas pelayanan USG tidak tersedia. Dari hasil pengukuran tinggi fundus uteri, pertumbuhan janin dan taksiran berat janin dapat diperkirakan. Selanjutnya, melalui pemeriksaan tinggi fundus uterus, terdapatnya kelainan letak dan bagian presentasi janin, dan posisi janin dapat juga diperkirakan (Reeder, dkk, 1997).

Terdapat beberapa rumus yang menggunakan Tinggi Fundus Uteri (TFU) yang sering dan mudah dipakai untuk menaksir berat badan bayi yang lahir, antara lain adalah rumus Niswander, rumus modifikasi dari Niswander (Farid dan Sukarya, 1999), rumus Johnson, rumus SFH dan rumus SML. Namun, penggunaan rumus-rumus tersebut belum banyak diujikan terhadap populasi ibu hamil di Indonesia.

Kurangnya penelitian tentang kesesuaian rumusrumus ini terhadap populasi Indonesia mendorong peneliti untuk meneliti bagaimana keakuratan rumusrumus tersebut dalam memprediksi berat badan janin yang akan lahir. Oleh karena itu, penelitian ini bertujuan untuk membandingkan penggunaan rumus Niswander, Johnson, SML, SFH, dan modifikasi Niswander untuk mengestimasi berat badan janin yang akan lahir pada populasi ibu-ibu di Indonesia, dengan sample penelitian ini di Jakarta.

\section{BAHAN DAN CARA KERJA}

Desain yang digunakan dalam penelitian ini adalah potong lintang (cross-sectional design) dengan pengambilan data dilakukan hanya satu kali dengan menggunakan catatan rekam medik. Nilai pengukuran yang dipakai adalah nilai pengukuran TFU terakhir dari ibu yang akan melahirkan.
Penilaian taksiran berat badan janin diperoleh dari hasil perhitungan rumus-rumus dengan nilai TFU yang telah diperoleh dari pengukuran yang kemudian dibandingkan dengan berat badan bayi mereka yang baru dilahirkan (berat badan aktual).

Populasi dalam penelitian ini adalah semua ibu hamil, baik primipara maupun multipara yang memeriksakan kehamilan dan akan melahirkan bayibayi mereka di Puskesmas Tebet, Jakarta selama kurun waktu Februari - Mei 2003. Sedangkan sampel yang akan diambil harus memenuhi kriteria inklusi yang telah ditetapkan. Adapun kriteria inklusi yang ditetapkan adalah sebagai berikut: umur kehamilan 36-40 minggu, janin tunggal, tidak mengalami kelainan letak plasenta, tidak mengalami penyakit kronik seperti penyakit ginjal, hipertensi, jantung, diabetes mellitus gestasional, dan bersedia menjadi responden penelitian. Pengambilan data berdasarkan catatan rekam medis dengan memperhatikan kriteria inklusi yang telah ditetapkan.

Analisis data yang digunakan adalah uji $t$ beda satu sampel untuk menguji validitas masing-masing rumus estimasi berat badan lahir janin. Sedangkan hubungan umur dan jumlah paritas dengan berat badan bayi yang baru lahir diuji dengan dengan test Anova. Nilai kemaknaan yang digunakan adalah $5 \%$.

\section{HASIL}

Selama periode pengambilan data antara bulan Februari hingga Mei 2003, didapatkan data dari 223 responden yang memenuhi kriteria inklusi. Pelaksanaan pengumpulan data dilakukan di Puskemas Pembina Tebet, Jakarta. Hasil penelitian ini disajikan dalam bentuk tabel.

Tabel 1

Distribusi ibu hamil menurut umur

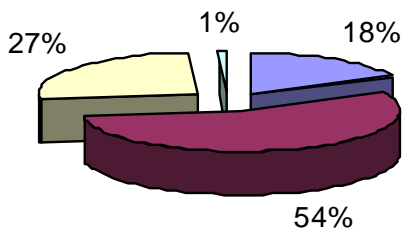


Jurnal Keperawatan Indonesia, Volume 8, No. 1, Maret 2004; 18-22

Dari tabel di atas diketahui bahwa distribusi ibu hamil terbanyak ada pada ibu berumur 21-29 tahun, yaitu $54,7 \%$ dengan berat lahir rata-rata 3160,9 gr namun apabila umur ibu lebih dari 40 tahun maka berat bayi yang dilahirkan menurun kembali, yaitu 2850 gr . Berat badan rata-rata terendah, yaitu 3118, gr pada umur ibu hamil $\leq 20$ tahun kemudian 3160,9 gr pada umur ibu antara 21-29 tahun, dan tertinggi 3216,7 gr pada ibu berumur 30-39 tahun dan menurun pada umur ibu $>40$ tahun, yaitu 2850 gr. Setelah dilakukan uji Anova ternyata diketahui ada perbedaan yang bermakna antara umur dengan berat badan bayi yang dilahirkan $(\mathrm{p}=0,000)$

Tabel 2

Distribusi ibu hamil menurut paritas dan rata-rata berat badan lahir

\begin{tabular}{crrrr}
\hline Paritas & N & Persentase & Rata-rata BB lahir & Nilai P \\
\hline 1 & 81 & 37.3 & $3086.4 \mathrm{gr}$ & 0.047 \\
\hline $2-4$ & 128 & 58.9 & $3220.4 \mathrm{gr}$ & \\
\hline$\geq$ & 8 & 3.8 & $3125.0 \mathrm{gr}$ & \\
\hline
\end{tabular}

Distribusi ibu hamil menurut paritas dan rata-rata berat bayi yang dilahirkan dapat dilihat pada tabel 2. Terbanyak ibu dengan paritas antara 2-4 $(58,9 \%)$. dengan rata-rata berat bayi yang dilahirkan adalah 3220,4 gr. Terdapat kecenderungan peningkatan berat bayi yang dilahirkan pada ibu primipara dengan ibu multipara, yaitu dari 3086,4 gr menjadi 3220,4 gr namun menurun pada ibu grandpara, yaitu 3125,0 gr. Setelah dilakukan uji Anova, diketahui terdapat perbedaan yang bermakna antara paritas dengan berat bayi yang dilahirkan $(\mathrm{p}=0,047)$. Dengan uji lanjut, yaitu dengan tes Bonferroni diketahui bahwa perbedaan yang terjadi adalah antara berat badan bayi yang dilahirkan pada ibu primipara dengan ibu multipara $(\mathrm{p}=0,0420)$.
Tabel 3

Distribusi berat badan lahir dan prediksi berat badan lahir menurut beberapa rumus

\begin{tabular}{llrrr}
\hline No. & \multicolumn{1}{c}{ Rumus. } & $\begin{array}{c}\text { Mean } \\
(\mathrm{GR})\end{array}$ & SD (GR) & $\begin{array}{c}\text { Nilai } \\
\mathrm{P}\end{array}$ \\
\hline 1. & Berat baan lahir & 3165.5 & 378.5 & \\
\hline 2. & Niswander & 3299.5 & 327.5 & 0.000 \\
\hline 3. & $\begin{array}{l}\text { Modifikasi niswander } \\
\text { (Farid \& Sukarya) }\end{array}$ & 3133.3 & 242.9 & 0.205 \\
\hline 4. & SFH & 3383.1 & 391.4 & 0.000 \\
\hline 5. & SML & 3642.4 & 1314.3 & 0.000 \\
\hline 6. & Johnson & 3541.9 & 336.2 & 0.000 \\
\hline
\end{tabular}

Ket :

$\mathrm{BBL}=$ Berat badan lahir sebenarnya

Niswander $=\frac{\text { TFU }-13}{3} \times 453,6 \mathrm{gr}$

Modifikasi Niswander (Farid dan Sukarya) : (1,12 TFU - 7,7) 100

$\mathrm{SFH}=(0,18 \mathrm{TFU})-2,89$

$\mathrm{SML}=(119,3 \mathrm{TFU})+(12,2 \mathrm{~TB})+2487,9$

Johnson $=($ TFU -12$) 155$

Pada tabel 3 dapat diketahui bahwa bahwa ratarata taksiran terbesar berasal dari dari rumus SML, yaitu 3642,4 gr sedangkan taksiran yang paling mendekati berat bayi yang sebenarnya adalah dari rumus Modifikasi Niswander, yaitu 3133,3 gr.

Setelah dilakukan analisis statistik dengan uji t beda 1 mean diketahui bahwa hanya rumus modifikasi Niswander yang mengestimasi berat badan janin tidak berbeda dengan berat lahir bayi secara aktual $(\mathrm{p}=0,205)$. Sedangkan rumus-rumus yang lain diketahui ada perbedaan yang bermakna antara estimasi dengan berat lahir aktual. Perbedaan taksiran terbesar pada rumus SML $(\mathrm{p}=0,000)$, kedua pada rumus Johnson $(\mathrm{p}=0,00)$ terakhir pada rumus Niswander $(p=0,000)$. Secara umum dapat disimpulkan bahwa dari keempat rumus diatas yang dapat digunakan untuk mengestimasi berat lahir bayi dan paling valid adalah rumus modifikasi Niswander (Farid \& Sukarya, 1999). 


\section{PEMBAHASAN}

Dalam penelitian ini ditemukan bahwa semakin tua usia ibu maka kecenderungan yang terjadi adalah bayi yang dilahirkan mengalami peningkatan berat badan lahir atau besar masa kehamilan, namun pada umur ibu > 40 tahun ditemukan bahwa berat bayi yang dilahirkan menurun kembali dan perbedaan ini sangat bermakna dengan nilai $\mathrm{p}=0.000$ (lihat tabel 1). Hal yang serupa didapatkan pada penelitian Rosmina, dkk, (2003) yang mendapatkan hasil bahwa dari $359 \mathrm{ibu}$ hamil, rata-rata berat badan lahir bayi meningkat sesuai usia ibu, namun kebanyakan pada usia ibu hamil > 40 tahun, bayi-bayi yang dilahirkan dari ibu-ibu tersebut kembali cenderung mengalami penurunan berat badan lahir. Berbagai factor kemungkinan dapat terjadi dengan kondisi tersebut adalah berat badan lahir bayi turut dipengaruhi oleh faktor keadekuatan vaskulasisasi atau pun penyakit-penyakit sistemik yang diderita para ibu di usia tua (Pilliteri, 1999). Selain itu faktor proses penuaan (aging process) pada ibu-ibu setelah berusia lebih dari 40 tahun, juga turut berkontribusi terhadap status berat badan lahir bayibayi yang mereka lahirkan (Reeder, 1997).

Penemuan selanjutnya dari penelitian ini mendapatkan bahwa ada peningkatan yang bermakna pada berat badan lahir antara primipara dengan multipara dalam (lihat tabel 2). Rata-rata berat lahir terendah pada primipara (paritas 1) kemudian meningkat pada multipara (paritas 1-3) namun kemudian menurun kembali pada ibu grandmultipara (paritas $>3$ ). Hasil serupa didapatkan pada penelitian Rosmina, dkk., (1999). Dari hasil tersebut dapat dianalisis bahwa, pada umumnya faktor pengalaman maternal dan keadekuatan faktor vaskularisasi maternal-plasenta mempengaruhi perolehan hasil akhir suatu kehamilan (Reeder, 1997). Pada ibu-ibu primipara, factor belum memiliki pengalaman, terutama terhadap diet nutrisi yang mereka konsumsi selama masa hamil turut berkontribusi terhadap status berat badan lahir dari bayi-bayi yang mereka lahirkan. Pada sisi lain, ibuibu dengan status paritas grademultipara pada umumnya melahirkan bayi-bayi dengan berat badan lahir yang lebih rendah. Keadaan ini ditunjang dengan suatu rasionalisasi bahwa factor menurunnya keadekuatan vaskularisasi utero-plasenta (pada ibu- ibu grandemultipara) yang berkontribusi dalam menyalurkan bahan makanan untuk pertumbuhan janin mendukung hasil temuan penelitian ini

Alat yang sering dipakai untuk mengestimasi berat badan lahir adalah Ultrasonografi (USG). Alat ini diketahui memiliki sensitivitas yang tinggi untuk mengestimasi berat badan lahir, namun kelemahan alat tersebut adalah tidak semua fasilitas kesehatan terutama di Indonesia mempunyai alat ini. Selain USG, variabel sederhana yang dapat digunakan untuk menaksir berat badan lahir adalah mengukur Tinggi Fundus Uteri (TFU). Banyak penelitian yang dilakukan untuk membandingkan antara penggunaan alat USG dengan pengukuran TFU. Umumnya hasil dari penelitian tersebut menyimpulkan bahwa pengukuran TFU dapat dipakai untuk memperkitrakan umur kehamilan dan estimasi berat badan lahir (Euans, dkk, 1995, Belizan, dkk, 1978, Persson, dkk 1986, Calvert, dkk, 1982, Indira, dkk, 1990, Quaranta, dkk, 1981).

Ada beberapa rumus yang menggunakan pengukuran TFU sebagai variabel utama untuk menduga berat badan lahir, dan pada penelitian ini diteliti validasinya untuk populasi Jakarta. Dalam penelitian ini didapatkan hasil bahwa semua rumus yang ditemukan para peneliti Barat ternyata kurang sesuai untuk mengestimasi berat badan lahir (rumus Niswander, Johnson, dan SFH) untuk populasi di Indonesia. Hal ini dimungkinkan karena adanya perbedaan ras. Euans, dkk, 1995 dalam penelitiannya menyatakan bahwa pengukuran TFU dapat menggantikan pengukuran USG namun pengukuran ini dipengaruhi oleh ras. Hasil serupa dilaporkan Rosmina, dkk, 2003 dalam penelitiannya yang dilakukan di RS Manado pada 359 ibu hamil. Penelitian tersebut membandingkan penggunaan rumus Johnson dengan rumus SML dalam menaksir berat badan lahir. Hasilnya menyimpulkan bahwa rumus Johnson kurang baik mengestimasi berat badan lahir. Hasil estimasi yang didapatkan cenderung lebih tinggi daripada berat badan lahir aktual.

Penggunaan rumus SML yang didapatkan oleh Subagio, dkk, 2000 di RS Manado telah diuji coba oleh Rosmina, dkk, 2003. Rumus SML selain memakai pengukuran TFU sebagai prediktor juga 
memakai variabel tinggi badan ibu. Rosmina, dkk, 2003 mendapatkan hasil bahwa estimasi berat badan lahir dari rumus tersebut berbeda bermakna dari berat badan lahir sesungguhnya. Hasil penelitian ini juga menyimpulkan hal yang serupa, bahwa estimasi berat badan yang dihasilkan lebih tinggi daripada berat badan lahir aktual, sehingga rumus ini kurang tepat dipakai untuk menaksir berat badan lahir pada populasi Indonesia.

\section{KESIMPULAN}

Berdasarkan hasil analisis dan pembehasan penelitian ini, dapat disimpulkan sebagai berikut:

1. Semakin meningkat umur ibu maka cenderung bayi yang dilahirkan mengalami peningkatan berat badan namun peningkatan tersebut tidak bermakna $(\mathrm{p}=0,581)$

2. Ada peningkatan yang bermakna pada berat badan lahir antara primipara dengan multipara $(p=0,047)$.

3. Penggunaan rumus SML, Niswander, Johnson, dan SFH tidak cukup valid untuk menaksir berat badan lahiruntuk populasi Jakarta pada umumnya hasil taksiran lebih tinggi daripada berat badan lahir aktual $(\mathrm{p}=0,000)$

4. Modifikasi Niswander (Farid dan Sukarya, 1999) cukup baik untuk menaksir berat badan lahir. Hasil taksiran tidak berbeda bermakna dengan berat badan lahir aktual $(p=0,205)$

Dari penelitian ini menyimpulkan hanya rumus modifikasi Niswander dari Farid dan Sukarya yang valid untuk menaksir berat badan lahir janin. Kelemahan dari rumus ini adalah tidak mudah untuk diingat (belum sederhana) dan memerlukan suatu alat bantu untuk mendapatkan hasil perhitungan akhir. Berdasarkan hal tersebut, penelitian ini merekomendasikan untuk dilakukan penelitian selanjutnya untuk menemukan rumus baru yang lebih sederhana untuk diingat dan sesuai untuk populasi di Indonesia (INR).

* Dewi Gayatri, S.Kp., M.Kes.: Staf pengajar bagian dasar keperawatan dan keperawatan dasar FIK-UI

** Yati Afiyanti, S.Kp., MN.: Staf pengajar bagian keperawatan maternitas dan anak FIK-UI

\section{KEPUSTAKAAN}

Alibasjah RW dan Hakimi M (1995). Deteksi janin tumbuh lambat: kesepakatan diagnosis antara pengukuran tinggi fundus uteri dan pengukuran biometri janin secara ultrasonografik. Berkala ilmu kedokteran 27 (3) : 143-50

Belizan JM, Villar J, Nardin JC, Malamud J, and de Vicuna LS (1978). Diagnosis of intrauterine growth retardation by simple clinical method: Measurement of uterine height. Am J obstet Gynecol. 131: 643-6

Bothner BK, Gulmezoglu AM, \& Hofmey GJ. (2000). Symphisis fundus height measurements during labour : a prospective, descriptive study. African Journal of Reproductive Health 4(1):48-55

Calvert. JP, Crean E, Newcombe RG, Pearson JF(1982). Antenatal screening measurement of symphysis-fundal height. Br Med J 285(6345) : 846-9

Euans DW, Connor PD, Hahn RG, dkk (1995). A comparison of manual and ultrasound measurements of fundal height. J Fam Pract 40:233-6

Farid dan Sukarya. W.S. (1999). Taksasi berat badan anak berdasarkan modifikasi rumus Niswander. Majalah Obstetri dan ginekologi Indonesia 23 (4) :188-93

Indira R, Oumachigui A, Narayan KA, dkk (1990). Symphysisfundal height measurement- a reliable parameter for assessment of fetal growth. Int J Gynaecol Obstet 33(1):1-5

Mardipuro S (1989). Pondok bersalin desa, suatu alternatif dalam upaya peningkatan safe motherhood di pedesaan. Medika $8: 652-7$

Mhaskar R, Mhaskar SR, \& Molly SR. Symphysiofundal height (SFH) measurement forprediction of birth weight-a new formula. Http//www. google.com. diakses tanggal 3 September 2003

Niswander JC, Martin JN, Martin RW et al (1970). Estimation of birth weight by quatified external uterine measurenlments. Obstet Gynecol 36:294-8

Persson B, Stangenberg M, Lunell No, Brodin U, dkk (1986). Prediction of size of infants at birth by measurement of symphysis fundus height. Br J Obstet Gynecol 93(3): 206-211

Pillitery, A. (1999). Maternal \& child health nursing: care of the childbearing \& childrearing family (3 rd ed.). Philadelphia: Lippincott.

Quaranta P, Currel R, Redman CWG, Robinson JS (1981). Prediction of small for dates infantas by measurement of symphysial fundal height. Br J Obstet Gynecol 88:115-9

Reeder, S.J., Martin, L.L. \& Koniak-Griffin, D. (1997). Maternity nursing: family newborn and women's health care (18 th ed.). Philadelphia: Lippincott.

Rosmina S, Masengi JA, \& Loho MT (2003). Perbandingan ketepatan mengestimai berat badan lahir menurut rumus Johnson dan rumus SML. Majalah Obstetri Ginekologi Indonesia 27(1):14-20 